\title{
The production and testing of staphylococci with clumping factor activity for use in the assay of fibrinogen degradation products
}

\author{
G. RICHARDSON
}

From the Microbiology Section, School of Pharmacy, Portsmouth Polytechnic, Portsmouth

SYNOPSIS A method for the large-scale production of a staphylococcal preparation for use in the assay of fibrinogen degradation products is described. The material is assayed against a fibrinogen standard and is shown to be stable over long periods and of high sensitivity. The possibility of production on an occasional basis in a routine laboratory is discussed.

Much recent literature testifies to the current interest in the clinical significance of fibrinogen and fibrinogen degradation products (FDP). Several techniques, differing widely in methodology, are available for assay of these materials. Examples include methods based on haemagglutination inhibition (Merskey, Lalezari, and Johnson, 1969), the highest clotting dilution and protein content of clot (Giddings and Bloom, 1971), heat precipitation (Millar, Simpson, and Stalker, 1971), antibody-coated latex particles (Garvey and Black, 1972), counterelectrophoresis (Brody, 1972), and clumping of staphylococci (Hawiger, Niewiarowski, Gurewich, and Thomas, 1970). Of the various comparisons which have been made, that by Thomas, Niewiarowski, Myers, Bloch, and Colman (1970) is particularly worthy of note.

The staphylococcal clumping test has received much critical examination. The clinical usefulness of the test has been established in that there is generally good correlation between the raised FDP levels associated with fibrinolytic conditions as shown by this test and other tests (Allington, 1967; Hawiger et al, 1970; Thomas et al, 1970; Leavelle, Mertens, Bowie, and Owen, 1971b). This is perhaps surprising in view of the fact that the staphylococcal clumping test is more sensitive to 'early' FDP than 'late' FDP (Allington, 1967). However, it has been shown (Leavelle, Bowie, Mertens, McDuffie, and Owen, 1971a) that the staphylococcal clumping test is also sensitive to complexes between 'late' FDP and fibrinogen which are likely to occur during clotting of the patient's plasma. Thus in practice the staphylococcal clumping test is a sensitive test for FDP and correlates well with other methods.

Received for publication 19 March 1973.
Although the assay based on staphylococcal clumping is the subject of several reports, preparations of the bacterial cells are not commercially available. In response to a request for a supply of this material for use in clinical trials (Leslie, personal communication) several hundred $10 \mathrm{mg}$ ampoules of the material were prepared in these laboratories. The method was based on that of Hawiger et al (1970) adapted for use on a production scale basis. This report offers recommendations for such production in the light of experience gained and considers the possibility of preparation of the material on a smaller scale on a day-to-day basis in the hospital laboratory.

\section{Materials and Methods}

PRODUCTION OF STAPHYL OCOCCAL

CLUMPING FACTOR

Staphylococcus aureus $\mathrm{D}_{2} \mathrm{C}$ Newman (coagulase - ve, clumping factor + ) was grown at $37^{\circ} \mathrm{C}$ in 21 of a medium composed of Trypticase 15 , Lablemco 10 , dextrose 5, $\mathrm{NaCl} 2$, and $\mathrm{Na}_{2} \mathrm{HPO}_{4} 1 \mathrm{~g} / 1$, for 20 hours. The growth vessel was a Porton type 21 fermenter equipped with facilities for controlling and recording $\mathrm{pH}$, which was maintained at the initial value of $7.0 \pm 0.2$ by the addition of $\mathrm{N} / 1 \mathrm{HCl}$ or $\mathrm{NaOH}$. In a typical run this resulted in the addition of about $100 \mathrm{~cm}^{3}$ alkali and $40 \mathrm{~cm}^{3}$ acid. Aeration was at the rate of $21 / \mathrm{min}$ and foaming controlled by the discontinuous addition of $5 \%$ solution of silicone MS antifoam emulsion RD (Hopkins \& Williams). The cells were harvested in a continuous flow centrifuge, resuspended in $0.85 \% \mathrm{NaCl}$ and heated at $70^{\circ}$ for 90 minutes. After washing twice with water the cells were resuspended in water to give approximately $\mathbf{4 0}$ 
$\mathrm{mg}$ dry weight $/ \mathrm{cm}^{3}$ and $0.25 \mathrm{~cm}^{3}$ aliquots were freeze dried in a centrifugal freeze-drier to a final vapour pressure of 0.05 torr. The ampoules were sealed in air and stored at $4^{\circ} \mathrm{C}$.

ASSAY OF CLUMPING FACTOR

Each batch was routinely tested against a fibrinogen standard. The contents of an ampoule were reconstituted to an approximate concentration of 10 $\mathrm{mg} / \mathrm{cm}^{3}$ using $1 \mathrm{~cm}^{3}$ of Tris-albumin buffer $(0.2 \mathrm{M}$ Tris containing $0.01 \%$ bovine albumin, $\mathrm{pH} 7.4$ ). Serial dilutions of fibrinogen (Kabi, human, grade L) were made in Tris-salt buffer $(0.2 \mathrm{M}$ Tris containing $0.56 \% \mathrm{NaCl}, \mathrm{pH} 7 \cdot 4)$. Equal volumes $\left(0.2 \mathrm{~cm}^{3}\right)$ of cell suspension and fibrinogen dilutions were placed in the wells of a Sterilin disposable migration chamber (the flat-bottom cavities are more suitable for observing results than the concavities of a WHO plate) and mixed by gentle rocking for two minutes. Clumping was observed against a black background. A control of suspension plus Tris-salt buffer was used to demonstrate freedom from autoagglutination and the sensitivity of the cell preparation expressed as the final concentration of fibrinogen in the highest doubling dilution showing clumping.

One batch was additionally tested against products of fibrinogenolysis. For this purpose FDP were prepared by the digestion of fibrinogen by streptokinase or plasmin according to Allington's (1967) method. Preparations were tested after $90 \mathrm{~min}$ at $37^{\circ} \mathrm{C}$.

A further comparison was made between the behaviour of SCF and antibody-coated latex particles to fibrinogen and to FDP. In this test the Thrombo-Wellcotest latex suspension (Wellcome Reagents Ltd) was used.

\section{Results and Discussion}

\section{ROUTINE PRODUCTION}

The aim of the routine production was to produce a good yield of cells with high clumping factor activity. To encourage rapid growth and high cell yield dextrose was included in the aerated medium. In the expectation that this might lead to problems associated with acid production, $\mathrm{pH}$ was controlled throughout at $7 \cdot 0$. Fourteen batches were prepared in this way, with a cell yield of 10 to $12 \mathrm{~g}$ moist cells $/ 2$ litres (equivalent to about $3 \mathrm{~g}$ dry weight) with fibrinogen sensitivity usually within the range 0.01 $0.05 \mu \mathrm{g} / \mathrm{cm}^{3}$.

The performance of one batch of staphylococcal clumping tests was tested against FDP as well as fibrinogen and results were compared with those from a latex particle test. Original sensitivity to fibrinogen of this batch of staphylococcal clumping tests was
$0.015 \mu \mathrm{g} / \mathrm{cm}^{3}$ and of the latex particles was $1 \mu \mathrm{g} / \mathrm{cm}^{3}$. When tested against the lysed fibrinogen, sensitivity of SCT had fallen at least 100 -fold and the latex particles had similarly lost sensitivity.

Technical difficulties arising in production were twofold. First, there was an unacceptably high rate of breakage of ampoules during freeze drying. This was apparently due to the relatively high eutectic point (Verma and Rowe, 1959) of the aqueous cell suspension. An attempt was made to overcome the problem by comparing the effect on sensitivity of freeze drying aqueous suspensions and suspensions in Tris-albumin buffer in both untreated and in Repelcote (Hopkins \& Williams)-treated ampoules. Both treatments reduced the breakage level to negligible proportions and a comparison of test samples with controls showed no loss in sensitivity. It thus seems advisable in any subsequent routine $O$ preparation to make a final suspension in Trisalbumin buffer before freeze drying, thus also removing the need for the buffer as a stock solution for reconstitution purposes.

Secondly, the normal cell yield was considerably greater than could be handled by the freeze-drier (maximum capacity 100 ampoules) in one operation. In view of the fact that the most time-consuming part of the operation was the initial setting up of the culture vessel, rejection of cell yield at this latter stage was unacceptable and an attempt was made to discover how the cells might be stored after harvesting without loss of sensitivity until the freeze drying facility was available again. Storage at $-20^{\circ}$ proved useless as it caused autoagglutination. In a comparative trial a final cell suspension was made in water or in $0.85 \% \mathrm{NaCl}$ and stored at $4^{\circ}$ for five days. Cells were heated at $70^{\circ}$ either before or after storage. In general such treatment had little effect on the retention of sensitivity during storage before freeze drying, although the clearest endpoint was from $\mathrm{NaCl}$ suspensions heated before storage. Leavelle et al (1971b) have found the bacterial suspension to be stable for several days in imidazolesaline.

SMALL-SCALE ALTERNATIVES

On the large scale submerged fermentation is the method of choice since it offers, amongst other, facilities for adequate aeration and control of $\mathrm{pH}$.

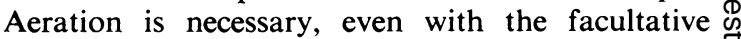
Staphylococcus, to achieve high cell yield and in the presence of dextrose-containing medium it seemed that $\mathrm{pH}$ control would be necessary to counteract the early rapid fall in $\mathrm{pH}$ which occurs in carbohydrate-containing media. In the hospital laboratory adequate aeration can be obtained by the simple expedient of using surface culture. This avoids 
the need for forced aeration or shaking flasks; both processes are technically more demanding and simple flask shakers may not give efficient aeration. An investigation was therefore made into the feasibility of producing cells on solid media.

Cells were grown on $20-\mathrm{cm}$ square aluminium trays filled to varying depths with the original medium, solidified by the inclusion of $1 \%$ agar. The yield of cells, harvested after $20 \mathrm{hr}$, was $1.0 \pm 0.1 \mathrm{~g} /$ tray independent of the volume of agar, over the range tested $\left(200 \mathrm{~cm}^{3}\right.$ to $\left.1000 \mathrm{~cm}^{3}\right)$. Cells were devoid of clumping factor activity although the $\mathrm{pH}$ fell only to $5 \cdot 2$ (cf 3.8 in $\mathrm{pH}$ uncontrolled submerged culture). This procedure was repeated omitting dextrose from the medium to reduce further the fall in $\mathrm{pH}$. The yield of cells was higher $(1.5 \mathrm{~g} /$ tray $)$ but the cells were not fully sensitive (actual values $1-10 \mu \mathrm{g} / \mathrm{cm}^{3}$ ). Surface growth of cells offers the easiest means of producing a high yield of cells in a laboratory devoid of bulk deep-culture facilities and it seems that production of cells on solid media to give a preparation of adequate sensitivity is worth further investigation. McNeil (1966) has also found reduced sensitivity of cells from solid media; this is perhaps significant in view of the fact that material for detecting bound coagulase in a slide test is usually obtained from a plate culture.

Another alternative was the preparation of cells in small scale liquid culture using forced aeration. This can be provided cheaply on a small scale $\left(\mathrm{eg}, 500 \mathrm{~cm}^{3}\right)$ by the use of an aquarium aerator. With this in mind an attempt was made to grow cells under these conditions without $\mathrm{pH}$ control and with omission of dextrose from the medium to reduce the fall in $\mathrm{pH}$. The $\mathrm{pH}$ fell to $5 \cdot 2$; cells produced in this way were of similar sensitivity to those grown under standard conditions and the yield was almost identical. This method would therefore seem to have promise if it was desired to produce small quantities of material on a day-to-day basis.

\section{STABILITY OF PRODUCT}

Cells were stored at $4^{\circ}, 25^{\circ}$, and $37^{\circ}$ and assayed periodically against fibrinogen over a 12-month period. There was no loss in sensitivity in any sample.

\section{METHOD OF ASSAY}

The assay is intrinsically simple and the greatest source of variation is likely to be due to density of the cell suspension. This is due to technical difficulties in ensuring reasonable constancy in the weight of cells in each ampoule. It was found that over the cell density range $2 \cdot 5-40 \mathrm{mg} / \mathrm{cm}^{3}$ a doubling of cell concentration resulted in a halving of sensitivity and in the higher cell concentration range results were unclear due to unclumped cells. It seems desirable therefore that for reproducible work cells should be reconstituted to a fixed opacity, though this would not be necessary where the blood fibrinogen-FDP assay is performed on a comparative basis against a standard fibrinogen.

\section{Conclusions}

The bulk production of staphylococci with clumping factor activity by the routine methods of large-scale culture presents no difficulty. The activity of the cells is affected very little by environmental conditions and is remarkably stable. It is suggested that such production is worthy of commercial consideration as the staphylococcal clumping test has some merit. Since all methods of FDP assay do not detect the same stage in degradation and in a few cases do not equally demonstrate raised FDP levels in various clinical conditions, it has been suggested that it might be desirable routinely to use two different methods of assay. The staphylococcal clumping test might be one of these methods. In practice this test is one of the more sensitive methods and, with the proviso that cells are readily available, is one of the simplest assays to perform. The extreme sensitivity of the cells could, however, be a disadvantage in that it necessitates a high degree of dilution in testing. Further work might be directed to the production of cells of somewhat reduced sensitivity, and also towards definition of the conditions under which the test could be performed as a fixed single-dilution screening test.

The technical assistance of Miss P. Collins is gratefully acknowledged.

\section{References}

Brody, J. I. (1972). Detection of fibrinogen-fibrin degradation products by counterelectrophoresis. J. clin. Path., 25, 754-756.

Garvey, M. B., and Black, J. M. (1972). The detection of fibrinogen/ fibrin degradation products by means of a new antibody-coated latex particle. J. clin. Path., 25, 680-682.

Giddings, J. C., and Bloom, A. L. (1971). A study of two methods for estimating plasma fibrinogen and the effect of epsilon aminocaproic acid and protamine. J. clin. Path., 24, 467-471.

Hawiger, J., Niewiarowski, S., Gurewich, V., and Thomas, D. P. (1970). Measurement of fibrinogen and fibrin degradation products in serum by staphylococcal clumping test. J. Lab. clin. Med., 75, 93-108.

Leavelle, D. E., Bowie, E. J. W., Mertens, B. F., McDuffie, F. C., and Owen, C. A., Jr. (1971a). Assay for fibrinolytic split products: comparison of staphylococcal clumping and haemagglutination-inhibition tests. J. Lab. clin. Med., 77, 993-999.

Leavelle, D. E., Mertens, B. F., Bowie, E. J. W., and Owen, C. A. Jr. (1971b). Staphylococcal clumping on microtiter plates: a rapid simple method for measuring fibrinogen split products. Amer. J. clin. Path., 55, 452-457.

McNeil, E. M. (1966). The effect of cultural conditions on the production of clumping factor (bound coagulase) by Staphylococcus pyogenes. J. med. Lab. Technol., 23, 83-89.

Merskey, C., Lalezari, P., and Johnson, A. J. (1969). A rapid, simple, sensitive method for measuring fibrinolytic split products in human serum. Proc. Soc. exp. Biol. (N.Y.), 131, 871-875. 
Millar, H. R., Simpson, J. G., and Stalker, A. L. (1971). An evaluation of the heat precipitation 'method for plasma fibrinogen estimation. J. clin. Path., 24, 827-830.

Thomas, D. P., Niewiarowski, S., Myers, A. R., Bloch, K. J., and Colman, R. W. (1970). A comparative study of four methods for detecting fibrinogen degradation products in patients with various diseases. New Engl. J. Med., 283, 663-668.

Verma, N. S., and Rowe, T. W. G. (1959). The breakage of glass ampoules during freeze drying. Vacuum, 9, 21-27.

\section{The April 1973 Issue}

\section{THE APRIL 1973 ISSUE CONTAINS THE FOLLOWING PAPERS}

A trial of prophylactic replacement therapy in haemophilia and Christmas disease D. M. RAMSAY AND A. C. PARKER

Effects of changes in temperature (local and central) on plasma fibrinolytic activity B. DODMAN, W. J. CUNLIFFE, B. E. ROBERTS, AND C. W. BUCHAN

Selective media in the isolation of tubercle bacilli from tissues D. A. MITCHISON, B. W. ALLEN, AND R. A. LAMBERT

A comparison of methods for staining tubercle bacilli in histological sections N. GREENWOOD AND H. FOX

The Treponema pallidum haemagglutination (TPHA) test in biological false positive and leprosy sera M. F. GARNER, J. L. BACKHOUSE, G. DASKALOPOULOS, and J. L. WALSH

The reproducibility and use of the tritiated folic acid urinary excretion test as a measure of folate absorption in clinical practice: Effect of methotrexate on absorption of folic acid D. S. FREEDMAN, J. P. BROWN, D. G. WEIR, AND J. M. SCOTT

Indirect cutaneous immunofluorescence II Clinical significance THOMAS K. BURNHAM

A comparison of rapid methods including imprint cytodiagnosis for the diagnosis of breast tumours C. R. TRIBE

Lysozymuria and acute disorders of renal function J. F. HARRISON, R. W. PARKER, AND K. L. DE SILVA
Triglycerides, cholesterol, and phospholipids in normal heart papillary muscle and in patients suffer- $\overrightarrow{\vec{Z}}$ ing from diabetes, cholelithiasis, hypertension, and coronary atheroma M. ALAVAIKKO, RIITTA ELFVING. J. HIRVONEN, AND J. J ÄRVI

A comparative study of five laboratory tests for foeto-placental dysfunction in late pregnancy $D$. WATSON, S. A. SIDDIQUI, J. E. H. STAFFORD, S. GIBBARD. AND V. HEWITT

Reference method for the erythrocyte sedimentation rate (ESR) test on human blood INTERNATIONAL COMMITTEE FOR STANDARDIZATION IN HEMATOLOGY

\section{Technical methods}

Identification of Neisseria gonorrhoea and Neisseria meningitidis by a carbohydrate disc technique PETER STACEY AND GILLIAN WARNER

The oxidase activity of Chromobacterium s. K. DHAR AND R. JOHNSON

A screening test for IgG deficiency ANNE FERGUSON

A simple, inexpensive gel filtration technique for use in diagnostic serology J. R. PATTISON AND JENNIFER E. MACE

Wet ashing using a closed system GEORGE P. LEWIS AND LINDA L. COUGHLIN

Letters to the Editor

Book reviews

Copies are still available and may be obtained from the PUBLISHING MANAGER, BRITISH MEDICAL ASSOCIATION, TAVISTOCK SQUARE, LONDON, WC1H 9JR, price $£ 1.05$ 